\title{
BAURAN PEMASARAN DAN KINERJA USAHA INDUSTRI KECIL ROTI DI BANDAR LAMPUNG
}

\author{
(Marketing Mix and Bussiness Performance of Bread Micro Industry in Bandar Lampung)
}

Han Prahara Lukyta, Wuryaningsih Dwi Sayekti dan Suriaty Situmorang

Jurusan Agribisnis, Fakultas Pertanian, Universitas Lampung, Jl. Prof. Dr. Soemantri Brojonegoro No.1

Bandar Lampung 35141, e-mail: wuryaningsih.dwisayekti@fp.unila.ac.id

\begin{abstract}
This research aims to explore the perception of bread micro industry enterpreneurs about the marketing mix, the performance of bread micro industry, and the influence of the the perception on the performance. The research was conducted in Bandar Lampung using a survey method. The research location was selected purposively because Bandar Lampung city is one of the potential areas to developing bread micro industries. Data of this research were collected in. December 2016. The results showed that enterpreneurs' perceptions on marketing mixes, in terms of product, price, and promotion mixes are included in important category, while perception in place mix is included in important enough category. Based on the values of return on investment, profit margin, and operation ratio, the micro bakery industries in Bandar Lampung have been included in very good category. The enterpreneurs' perception on price mix influences the performance of micro bakery industry, while the other mixes do not influence the performance.
\end{abstract}

Key words: bread, marketing mix, micro industry, performance

\section{PENDAHULUAN}

Meningkatnya pertumbuhan ekonomi, teknologi, dan aktivitas pembangunan di berbagai bidang membawa segala sesuatunya ke arah yang lebih praktis dan efisien, termasuk dalam hal pemenuhan kebutuhan pangan. Hal tersebut berdampak pada adanya perubahan konsumsi masyarakat saat ini, menyukai jenis makanan instan dan siap saji menjadi alternatif yang dipilih. Salah satu perubahan konsumsi yang nyata terjadi adalah meningkatnya konsumsi makanan yang diolah dari tepung terigu seperti roti, mi, dan biskuit. Industri roti (bakery) merupakan bagian dari industri makanan jadi yang memanfaatkan tepung terigu sebagai bahan baku utama dalam proses produksinya.

Perkembangan yang terjadi pada industri kecil roti (bakery) beberapa tahun terakhir ini menunjukkan semakin meningkatnya minat para konsumen untuk mengkonsumsi roti (Kurniawan, 2010). Berkembangnya industri kecil roti dilatar belakangi oleh penduduk Indonesia yang tingkat pendidikannya relatif rendah serta mempunyai sedikit modal. Hal ini berdampak pada terbatasnya kegiatan ekonomi masyarakat, terutama bagi masyarakat yang mulai memasuki usia kerja, sehingga dengan bekal pendidikan serta modal yang rendah, maka pilihannya adalah bekerja atau membuka lapangan kerja di sektor industri kecil (Mubyarto, 1994).

Bertahannya industri kecil roti tidak hanya dipengaruhi oleh kualitas produk yang baik, namun juga harus didukung oleh strategi pemasaran yang baik sehingga produk yang dihasilkan dapat dipasarkan secara maksimal. Strategi pemasaran roti merupakan rencana menyeluruh, terpadu dan menyatu di bidang pemasaran, atau serangkaian tujuan sasaran dan kebijakan yang memberi arah kepada usaha-usaha pemasaran perusahaan dari waktu ke waktu, pada masing-masing tingkatan dan acuan serta alokasinya.

Salah satu strategi yang ada dalam strategi pemasaran adalah bauran pemasaran. Bauran pemasaran merupakan seperangkat alat pemasaran taktis dan terkontrol yang dipadukan oleh perusahaan. Bauran pemasaran terdapat 4 aspek, yaitu strategi produk, harga, promosi, dan distribusi, yang dikenal dengan strategi 4P (product, price, promotion, dan placement) yang harus sesuai (Kotler, 2000).

Pentingnya strategi pemasaran dan kinerja usaha menunjukkan bahwa diperlukan suatu analisis untuk melihat apakah industri kecil roti dapat menerapkan strategi pemasaran yang baik, sehingga industri kecil roti tidak mengalami kemunduran. Selain strategi pemasaran, kinerja 
usaha industri kecil roti juga merupakan faktor penting untuk kemajuan suatu industri kecil. Oleh sebab itu penelitian ini bertujuan untuk (1) mengetahui persepsi pengusaha terhadap bauran pemasaran (marketing mix) industri kecil roti, (2) menganalisis kinerja usaha industri kecil roti dan (3) mengetahui pengaruh persepsi bauran pemasaran terhadap kinerja usaha industri kecil roti di Kota Bandar Lampung.

\section{METODE PENELITIAN}

Metode yang digunakan dalam penelitian ini adalah metode survei. Lokasi penelitian ini adalah di Kota Bandar Lampung. Pemilihan lokasi dilakukan secara sengaja (purposive) dengan pertimbangan bahwa Kota Bandar Lampung merupakan salah satu daerah yang berpotensi untuk berkembangnya industri kecil roti di Bandar Lampung. Pengumpulan data dilaksanakan pada bulan Desember 2016.

Populasi dalam penelitian ini tidak diketahui karena tidak tersedia data indsutri kecil roti di Dinas Koperasi, Perindustrian dan Perdagangan, sehingga pemilihan sampel dilakukan dengan teknik snowball sampling. Pada penilitian ini jumlah sampel ditentukan sebanyak 30 responden, sesuai dengan teori Sugiyono (2013), yaiu bahwa ukuran sampel yang layak dalam penelitian adalah minimal 30.

Data yang digunakan dalam penelitian ini adalah data primer dan data sekunder. Data primer meliputi data penjualan dan biaya produksi, yang diperoleh dari responden industri kecil roti di Bandar Lampung dikumpulkan melalui teknik wawancara dengan menggunakan kuesioner (daftar pertanyaan) yang telah dipersiapkan. Data sekunder meliputi daftar industri kecil roti, diperoleh dari lembaga-lembaga atau instansi terkait, seperti Badan Pusat Statistik (BPS) Provinsi Lampung dan Dinas Koperasi, Perindustrian dan Perdagangan Provinsi Lampung, melalui studi literatur atau laporan publikasi yang sesuai dengan penelitian.

Sebelum kuesioner digunakan, terlebih dahulu dilakukan uji validitas dan reliabilitas. Uji validitas dianalisis pada semua variabel bauran pemasaran 4 $\mathrm{P}$ (product, price, place, and promotion). Hasilnya menunjukkan bahwa seluruh butir pertanyaan memiliki nilai Pearson Correlation atau t hitung lebih besar dari t tabel $(0,31)$ dan nilai ini lebih kecil dari signifikansi minimum 0,05. Nilai tersebut menunjukkan bahwa seluruh pertanyaan pada variabel bauran pemasaran $4 \mathrm{P}$ (product, price, place dan promotion) adalah valid.

Uji reliabilitas dianalisis pada semua variabel (produk, harga, tempat, dan promosi) yang menunjukkan bahwa Cronbach's Alpha variabel produk $\left(\mathrm{X}_{1}\right)$ adalah 0,93; harga $\left(\mathrm{X}_{2}\right)$ adalah 0,90; tempat $\left(\mathrm{X}_{3}\right)$ adalah 0,84 ; dan promosi $\left(\mathrm{X}_{4}\right)$ adalah 0,77 , seluruh variabel dalam kuesioner dinyatakan reliabel. Dilihat dari nilai Cronbach's Alpha lebih besar dari 0,70 (Azwar 2001). Nilai $\alpha>0,70$ menunjukkan bahwa seluruh pernyataan memiliki tingkat kehandalan yang baik dan dapat digunakan untuk dianalisis pada penelitian ini.

Penelitian ini menggunakan analisis deskriptif kuantitatif untuk menjawab tujuan pertama, dengan membuat kategori (lima kategori) untuk mengetahui persepsi bauran pemasaran industri kecil roti di Bandar Lampung. Garis kategorisasi dibuat berdasarkan item pernyataan untuk menilai variabel dan juga jumlah sampel yang digunakan. Rentang skor setiap kategori ditentukan dengan rumus (Sugiyono, 2013):

Rentang skor Kategori $=\frac{(\mathrm{JR} x J \mathrm{~J} \times \mathrm{ST})-(\mathrm{JR} \times \mathrm{JBxSR})}{\mathrm{ST}}$.

Keterangan :

JR : Jumlah responden

JB : Jumlah butir soal

ST : Skor tertinggi

SR : Skor terendah

Tujuan yang kedua yaitu untuk mengetahui kinerja usaha industri kecil roti di Bandar Lampung, dianalisis dengan perspektif keuangan, yang terdiri dari ROI (return on investment), profit margin dan rasio operasi. Ukuran kinerja usaha indsutri kecil roti di Bandar Lampung dilakukan berdasarkan klasifikasi sesuai dengan teori Kasmir (2008).

ROI (return on investment) merupakan salah satu bentuk dari rasio profitabilitas yang digunakan untuk dapat mengukur kemampuan perusahaan atas keseluruhan dana yang ditanamkan dalam aktiva. Semakin tinggi nilai ROI, maka semakin baik kinerja perusahaan dalam memanfaatkan aktiva. ROI dapat dihitung dengan rumus:

ROI $=\frac{\text { Laba setelah pajak }}{\text { Aktiva }} \times 100 \%$

Kriteria klasifikasi ROI adalah :

1. Return on Investment $\geq 30$ (Sangat Baik)

2. Return on Investment $24,00 \%-29,90 \%$ (Baik) 
3. Returrn on Investment $18,00 \%$ - 23,90 (Cukup Baik)

4. Returrn on Investment $12,00 \%$ - $17,90 \%$ (Kurang Baik)

5. Return on Investment $\quad 6,00 \%-11,90 \%$ (Tidak Baik)

Profit margin merupakan salah satu rasio rentabilitas yang menggambarkan profit yang dihasilkan oleh suatu perusahaan. Semakin tinggi nilai profit margin berarti semakin baik, karena perusahaan memiliki kemampuan dalam mendapatkan profit yang cukup tinggi. Profit margin dapat dihitung dengan rumus:

Profit Margin $=\frac{\text { Laba Bersih }}{\text { Penjualan }} \times 100 \%$

Kriteria klasifikasi profit margin adalah :

Profit margin $\geq 20,00 \%$ (Sangat Baik)

Profit margin 15,00\% - 19,90\% (Baik)

Profit margin 10,00\% - 14,90\% (Cukup Baik)

Profit margin 5,00\% - 9,90\% (Kurang Baik)

profit margin $0,00 \%-4,90 \%$ (Tidak Baik)

Rasio operasi merupakan operating assets yang berhubungan dengan penjualan bersih dan aktiva lancar yang dimiliki oleh perusahaan. Tingginya rasio operasi menunjukkan bahwa perusahaan dapat memanfaatkan aktiva lancar untuk meningkatkan penjualan bersih. Rasio operasi dapat dihitung dengan rumus:

Rasio Operasi $=\frac{\text { Penjualan Bersih }}{\text { Aktiva Lancar }} \times 100 \%$.

Kriteria klasifikasi rasio operasi adalah :

Rasio Operasi $\geq 110,00 \%$ (Sangat Baik)

Rasio Operasi 88,00\% - 109,90\% (Baik)

Rasio Operasi 66,00\% - 87,90\% (Cukup Baik)

Rasio Operasi 44,00\% - 65,90\% (Kurang Baik)

Rasio Operasi 22,00\% - 43,90\% (Tidak Baik)

Selanjutnya tujuan ketiga penelitian ini dianalisis menggunakan analisis regresi berganda, yaitu mengetahui pengaruh bauran pemasaran [Product $\left(\mathrm{X}_{1}\right)$, Price $\left(\mathrm{X}_{2}\right)$, Promotion $\left(\mathrm{X}_{3}\right)$, dan Place $\left.\left(\mathrm{X}_{4}\right)\right]$ terhadap kinerja usaha roti (Y) di Bandar Lampung. Model yang digunakan adalah (Gujarati, 2012):

$\mathrm{Y}=\mathrm{b}_{0}+\mathrm{b}_{1} \mathrm{x}_{1}+\mathrm{b}_{2} \mathrm{x}_{2}+\mathrm{b}_{3} \mathrm{x}_{3}+\mathrm{b}_{4} \mathrm{x}_{4}+\mu$

Keterangan:

$\mathrm{Y} \quad=$ Kinerja usaha industri kecil roti

$\mathrm{b}_{0} \quad=$ Intersep

$\mathrm{b}_{\mathrm{i}} \& \mathrm{a}_{\mathrm{i}}=$ Koefesien regresi $(\mathrm{i}=1,2,3,4)$
$\mathrm{X}_{1}=$ Product

$\mathrm{X}_{2}=$ Price

$\mathrm{X}_{3}=$ Promotion

$\mathrm{X}_{4}=$ Place

$\mu \quad=$ Random error

\section{HASIL DAN PEMBAHASAN}

\section{Karakteristik Responden}

Umur merupakan faktor penting yang akan mempengaruhi produktivitas kerja seseorang. Berdasarkan hasil penelitian diperoleh kisaran umur responden 26-51 tahun, dengan rata-rata 38 tahun, tergolong dalam usia produktif, yang merupakan usia ideal untuk bekerja dengan baik. Sebagian besar $(73,30 \%)$ pemilik industri kecil roti adalah laki-laki, yang menunjukkan bahwa usaha ini merupakan pekerjaan utama rumah tangga. Persentase terbesar $(70,00 \%)$ lama berusaha industri kecil roti di Bandar Lampung berada pada interval 5-8 tahun, yang menunjukkan bahwa para pengusaha industri kecil roti sudah cukup berpengalaman dalam menjalankan dan mengembangkan usahanya.

\section{Keadaan Umum Industri Kecil Roti}

Berdasarkan inventarisasi terhadap industri kecil roti di Bandar Lampung diperoleh sejumlah 30 industri kecil roti dengan karakteristik yang beragam. Uraian selanjutnya menyajikan karakteristik industri kecil roti menurut bahan baku, tenaga kerja, produksi, dan pemasaran.

\section{Bahan Baku}

Keberhasilan industri kecil roti di Bandar Lampung sangat ditentukan oleh ketersediaan bahan baku terigu. Industri kecil roti pada penelitian ini tidak sulit mendapatkan bahan baku, karena sudah bekerja sama dengan distributor yang mengantarkan bahan baku sampai ke tempat produksi.

\section{Tenaga Kerja}

Tenaga kerja yang digunakan oleh industri kecil roti merupakan tenaga kerja yang berasal dari dalam keluarga dan luar keluarga. Upah tenaga kerja industri kecil roti ini dibedakan sesuai dengan jenis pekerjaan masing-masing. Untuk pengadonan sebesar $\mathrm{Rp} 50.000,00$ sedangkan untuk aktivitas yang lain, seperti : pembentukan adonan, pencetakan adonan, pembakaran, dan pembungkusan adalah Rp 40.000,00 per hari. 


\section{Produksi}

Industri kecil roti di Bandar Lampung sebagian besar melakukan produksi setiap hari, akan tetapi frekuensi produksi pada masing-masing industri kecil berbeda-beda, mulai dari 26 hari sampai 27 hari dalam satu bulan. Frekuensi produksi pada hari besar, seperti Lebaran, berbeda dengan harihari biasa. Pada bulan yang ada libur hari besarnya, misalnya lebaran, maka frekuensi produksinya berkurang menjadi 23 hari per bulan. Frekuensi produksi akan mempengaruhi pendapatan yang diterima oleh pemilik industri kecil roti.

\section{Pemasaran}

Pemasaran oleh industri kecil roti dilakukan secara langsung dengan cara menyediakan outlet, dan pemasaran tidak langsung, yaitu melalui sales roti dan pengecer, yang berjualan di pasar tradisional

\section{Persepsi Pengusaha Industri Kecil Roti di Bandar Lampung Terhadap Bauran Pemasaran (Marketing Mix)}

Dalam penelitian ini persepsi pengusaha terhadap bauran pemasaran dianalisis untuk mengetahui unsur bauran pemasran (produk, harga, tempat dan promosi yang diperhatikan oleh pengusaha.

\section{Produk}

Hasil penelitian menunjukkan bahwa persepsi pengusaha terhadap tingkat kepentingan dari variabel produk, meliputi cara-cara yang dilakukan dalam penyediaan produk, didasarkan pada indikator rasa, bentuk, ukuran, merek, dan kemasan. Indikator tersebut dapat dikategorikan melalui garis kategorisasi seperti Gambar 1.

\begin{tabular}{|l|l|l|l|l|l|l|}
\hline $\begin{array}{l}\text { Tidak } \\
\text { Penting }\end{array}$ & $\begin{array}{l}\text { Kurang } \\
\text { Penting }\end{array}$ & $\begin{array}{l}\text { Cukup } \\
\text { Penting }\end{array}$ & Penting & $\begin{array}{l}\text { Sangat } \\
\text { Penting }\end{array}$ \\
\hline & & & & \\
\hline 150 & 270 & 390 & 510 & & 630 & 750 \\
\hline
\end{tabular}

Gambar 1. Garis kategorisasi persepsi pengusaha terhadap variabel produk industri kecil roti di Bandar Lampung

Nilai modus jawaban responden tentang persepsi pengusaha terhadap kepentingan variabel produk industri kecil roti di Bandar Lampung ada pada skor 4 (penting), dengan jumlah skor jawaban sebesar 582, artinya persepsi responden terhadap tingkat kepentingan strategi produk adalah penting.

\section{Harga}

Persepsi pengusaha terhadap tingkat kepentingan dari variabel harga yang meliputi cara-cara yang dilakukan pengusaha dalam menetapkan harga jual produk, didasarkan atas variasi harga dan potongan harga khusus. Indikator tersebut dapat dikategorikan seperti Gambar 2.

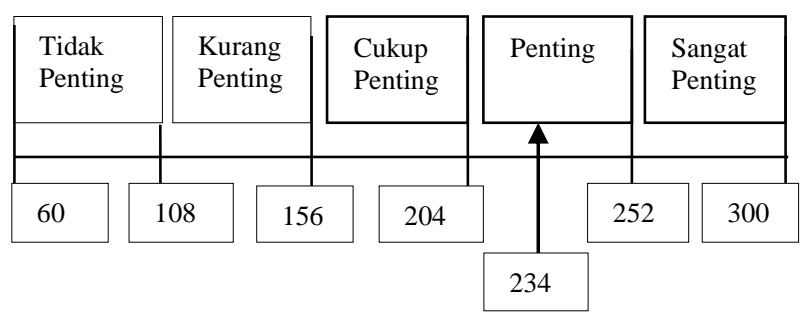

Gambar 2. Garis kategorisasi persepsi terhadap variabel harga industri kecil roti di Bandar Lampung

Nilai modus pada penilaian persepsi terhadap variabel harga adalah skor 4 (penting), dengan jumlah skor jawaban pada variabel harga adalah 234, artinya sebagian besar pemilik usaha indsutri kecil roti di Bandar Lampung mempunyai persepsi bahwa tingkat kepentingan variasi harga dan potongan harga adalah penting untuk diterapkan dan diperhatikan untuk menghadapi situasi dan kondisi pasar.

\section{Tempat}

Hasil penelitian menujukkan bahwa persepsi pengusaha terhadap tingkat kepentingan dari variabel tempat, didasarkan pada indikator saluran pemasaran, lokasi, cakupan pemasaran, dan persediaan produk. Indikator tersebut dapat dikategorikan seperti Gambar 3.

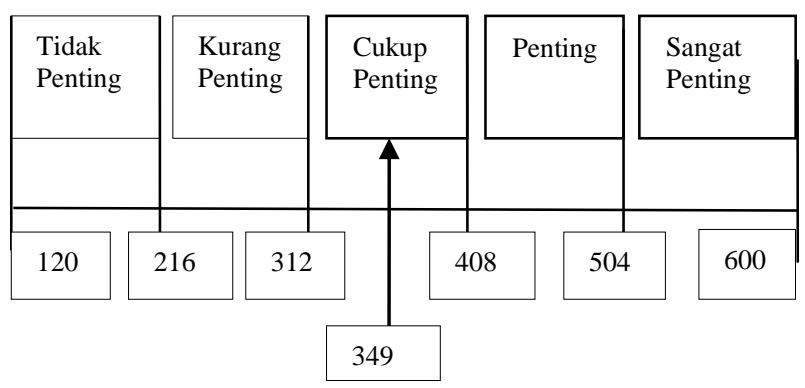

Gambar 3. Garis kategorisasi persepsi pengusaha terhadap variabel tempat industri kecil roti 
Nilai modus jawaban responden tentang persepsi pengusaha terhadap variabel tempat adalah skor 3 (cukup penting), dan jumlah skor jawaban adalah 349 , artinya responden menganggap cukup penting untuk melakukan dan memperhatikan tempat yang strategis untuk menarik konsumen membeli produk.

\section{Promosi}

Persepsi pengusaha terhadap tingkat kepentingan variabel promosi, yang meliputi pentingnya melakukan promosi serta tindakan yang dilakukan industri kecil roti di Bandar Lampung untuk mempromosikan produknya didasarkan pada indikator periklanan, publisitas, promosi penjualan, dan personal selling. Indikator tersebut dapat dikategorikan seperti Gambar 4.

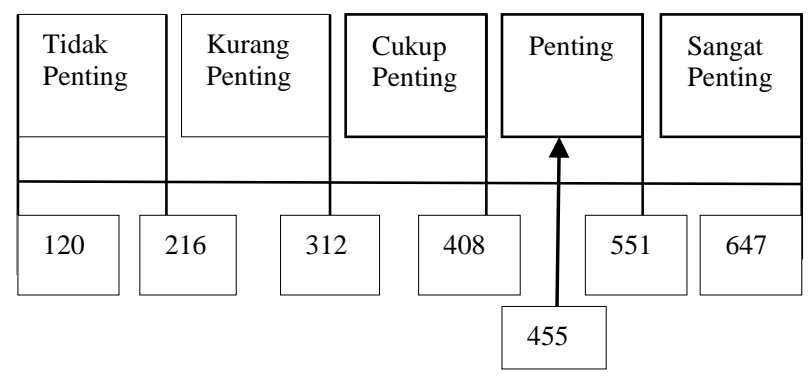

Gambar 4. Garis kategorisasi persepsi pengusaha terhadap variabel promosi industri kecil roti

Nilai modus jawaban pada penilaian persepsi pengusaha terhadap variabel promosi adalah skor 4 (penting), dengan jumlah skor jawaban sebesar 455, artinya responden menganggap penting menerapkan promosi melalui periklanan, publisitas, promosi penjualan dan personal selling.
Tabel 1. Distribusi industri kecil roti di Bandar Lampung menurut klasifikasi Return on Investment (ROI)

\begin{tabular}{clccc}
\hline $\begin{array}{c}\text { ROI } \\
(\%)\end{array}$ & Kategori & Skor & Jumlah & $\begin{array}{c}\text { Persentase } \\
(\%)\end{array}$ \\
\hline $6-11,90$ & Tidak baik & 1 & 0 & 0,00 \\
& Kurang & 2 & & 3,33 \\
$12-17,9$ & baik & & 1 & 23,33 \\
$18-23,9$ & Cukup baik & 3 & 7 & 10,00 \\
$24-29$ & Baik & 4 & 3 & 63,34 \\
& Sangat & 5 & 19 & 100,00 \\
\hline 30 & baik & & 19 & \\
\hline Total & & & 30 \\
\hline
\end{tabular}

\section{Kinerja Usaha Industri Kecil Roti di Bandar Lampung}

Kinerja usaha dianalisis untuk periode tahun 2016 dengan menggunakan prespektif keuangan yang terdiri dari ROI (return on investment), profit margin, dan rasio operasi, serta diklasifikasikan sesuai dengan teori Kasmir (2008).

\section{Return On Investment (ROI)}

ROI (return On investment) merupakan bentuk dari rasio profitabilitas yang digunakan untuk mengukur kemampuan industri kecil roti dalam menghasilkan keuntungan yang berasal dari keseluruhan dana aktiva. Penelitian ini menghasilkan distribusi industri kecil roti menurut klasifikasi ROI (return on investment) tahun 2016 dengan kisaran 6 sampai 30, seperti pada Tabel 1 .

Tabel 1 menunjukkan bahwa industri kecil roti dominan $(63,34 \%)$ berada pada kategori 5 (sangat baik), artinya modal yang diinvestasikan oleh industri kecil roti di Bandar Lampung tergolong ke dalam kategori sangat baik dalam pengembalian investasi modal usahanya.

Tabel 2. Distribusi industri kecil roti di Bandar Lampung menurut klasifikasi profit margin

\begin{tabular}{|c|c|c|c|c|}
\hline Profit margin $(\%)$ & Kategori profit margin & Skor & Jumlah & Persentase $(\%)$ \\
\hline $0-4,9$ & Tidak baik & 1 & 0 & 0,00 \\
\hline $5-9,9$ & Kurang baik & 2 & 0 & 0,00 \\
\hline $10-14,9$ & Cukup baik & 3 & 0 & 0,00 \\
\hline $15-19,9$ & Baik & 4 & 3 & 10,00 \\
\hline$\geq 20$ & Sangat baik & 5 & 27 & 90,00 \\
\hline Total & & & 30 & 100,0 \\
\hline
\end{tabular}


Tabel 3. Distribusi industri kecil menurut klasifikasi rasio operasi industri kecil roti di Bandar Lampung

\begin{tabular}{clccc}
\hline $\begin{array}{c}\text { Rasio } \\
\text { Operasi } \\
(\%)\end{array}$ & Kategori & Skor & Jumlah & $\begin{array}{c}\text { Persentase } \\
(\%)\end{array}$ \\
\hline $22-43,9$ & $\begin{array}{l}\text { Tidak baik } \\
\text { Kurang }\end{array}$ & 1 & 0 & 0,00 \\
& 2 & & \\
$44-65,9$ & baik & & 0 & 0,00 \\
$66-87,9$ & Cukup baik & 3 & 2 & 6,67 \\
$88-109,9$ & Baik & 4 & 6 & 20,00 \\
& Sangat & 5 & & \\
$\geq 110$ & baik & & 22 & 23,33 \\
\hline Total & & & 30 & 100,0 \\
\hline
\end{tabular}

\section{Profit Margin}

Profit margin merupakan selisih antara penjualan bersih dengan biaya operasi. Selisihnya dinyatakan dalam persentase terhadap penjualan bersih. Semakin rendah biaya operasional, maka semakin tinggi profit margin yang diperoleh oleh industri kecil roti. Hasil distribusi industri kecil roti di Bandar Lampung menurut klasifikasi profit margin dapat dilihat pada Tabel 2.

Berdasarkan Tabel 2 diketahui bahwa industri kecil roti dominan $(90,00 \%)$ berada pada kategori 5 (sangat baik), artinya industri kecil roti di Bandar Lampung dapat mengendalikan profit margin dengan biaya operasional dalam usahanya.

\section{Rasio Operasi}

Standar kisaran rasio operasi untuk distribusi industri kecil roti di Bandar Lampung adalah (22 sampai 110), distribusi industri kecil roti berdasarkan rasio operasi daoat dilihat pada Tabel 3.
Tabel 4. Kinerja usaha industri kecil roti di Bandar Lampung

\begin{tabular}{llccc}
\hline $\begin{array}{c}\text { Kinerja } \\
\begin{array}{c}\text { Usaha } \\
(\%)\end{array}\end{array}$ & Kategori & Skor & Jumlah & $\begin{array}{c}\text { Persentase } \\
(\%)\end{array}$ \\
\hline $12,0-12,5$ & Tidak baik & 1 & 5 & 16,66 \\
$12,6-13,1$ & Kurang & 2 & 3 & 10,00 \\
$13,2-13,7$ & baik & 3 & 0 & 0,00 \\
$13,8-14,3$ & Cukup baik & 4 & 10 & 33,34 \\
$14,4-15,0$ & Baik & 5 & 12 & 40,00 \\
& Sangat baik & & & \\
\hline Total & & & 30 & 100,00 \\
\hline
\end{tabular}

Pada Tabel 3 dapat dilihat bahwa industri kecil roti di Bandar Lampung (23,33\%) masuk dalam kategori 5 (sangat baik), artinya industri kecil roti di Bandar Lampung dapat memanfaatkan aktiva lancar yang dimiliki oleh industri kecil roti itu sendiri, sehingga dapat peningkatkan penjualan.Berdasarkan ROI (return on investment), profit margin dan rasio operasi, maka kinerja usaha industri kecil roti di Bandar Lampung dapat dihitung melalui penggabungan nilai-nilai kategori ROI (return on investment), profit margin dan rasio operasi tersebut. Selanjutnya dari penggabungan jumlah skor tersebut diklasifikasikan kembali. Skor gabungan dari masing-masing kinerja usaha berada pada kisaran 12,00 sampai 15,00 , sehingga pengklasifikasian kinerja usaha industri kecil roti di Bandar Lampung diperoleh seperti Tabel 4.

Pada Tabel 4 dapat dilihat bahwa kinerja usaha industri kecil roti di Bandar Lampung dominan (40.00\%), berada pada kategori sangat baik, artinya industri kecil roti pada tahun 2016 sudah sangat baik dengan hasil tingkat keberhasilan secara keseluruhan.

Tabel 5. Hasil analisis regresi dan signifikansi dari masing-masing variabel

\begin{tabular}{|c|c|c|c|c|c|c|c|}
\hline \multirow[b]{2}{*}{ No } & \multirow{2}{*}{ Model } & \multicolumn{2}{|c|}{ Unstandardized Coefficients } & \multirow{2}{*}{$\frac{\text { Standardized Coefficients }}{\text { Beta }}$} & \multirow{2}{*}{$\mathrm{T}$} & \multirow{2}{*}{ Sig. } & \multirow[b]{2}{*}{ VIF } \\
\hline & & B & Std. Error & & & & \\
\hline 1 & (Constant) & 1,97 & 0,91 & & 2,16 & 0,04 & \\
\hline 2 & Produk & 0,00 & 0,04 & 0,00 & $-0,00$ & 0,10 & 1,01 \\
\hline 3 & Harga & 0,29 & 0,09 & 0,54 & 3.17 & $0,00 *$ & 1,06 \\
\hline 4 & Tempat & $-0,01$ & 0,05 & $-0,02$ & $-0,11$ & 0,91 & 1,06 \\
\hline \multirow[t]{3}{*}{5} & Promosi & $-0,06$ & 0,05 & $-0,19$ & $-1,14$ & 0,27 & 1,03 \\
\hline & R square & 0,31 & & & & & \\
\hline & F hit & 2,77 & & & & 0,05 & \\
\hline
\end{tabular}




\section{Pengaruh Bauran Pemasaran terhadap Kinerja Usaha Industri Kecil Roti di Kota Bandar Lampung}

Pengaruh bauran pemasaran terhadap kinerja usaha industri kecil roti di Bandar Lampung dilakukan melalui analisis regresi. Hasil analisis regresi disajikan pada Tabel 5.

Berdasarkan regresi yang dilakukan, maka diperoleh nilai VIF dari variabel produk sebesar 1,01 , variabel harga sebesar 1,06 , variabel promosi sebesar 1,06, dan variabel tempat sebesar 1,03. Hasil regresi yang diperoleh menunjukkan bahwa tidak ada gejala multikolinieritas pada model regresi, karena nilai VIF dari variabel-variabel bebas kurang dari 10, sehingga dapat disimpulkan model regresi yang digunakan pada penelitian ini sudah baik.

\section{Koefisien Determinasi $\left(\mathbf{R}^{\mathbf{2}}\right)$}

Nilai koefisien determinasi pada penelitian ini adalah 0,30. Nilai tersebut memiliki arti bahwa sebesar 30 persen kinerja usaha industri kecil roti di Bandar Lampung dapat dijelaskan oleh variabel bebas yang dimasukan dalam model, yaitu produk, harga, tempat dan promosi, dan sisanya (70\%) dijelaskan oleh variabel lain yang tidak dimasukkan ke dalam model.

\section{Pengujian Serentak (Uji F)}

Pengujian serentak (Uji F) dilakukan untuk mengetahui apakah variabel bebas yang terdapat dalam penelitian secara bersama-sama nyata berpengaruh terhadap variabel terikat. Berdasarkan regresi yang telah dilakukan, maka diperoleh hasil F hitung sebesar 2,77 dengan signifikansi 0,05, sehingga dapat disimpulkan bahwa variabel produk, harga,tempat dan promosi secara bersamasama nyata berpengaruh terhadap kinerja usaha industri kecil roti di Bandar Lampung dengan tingkat kepercayaan sebesar 95,00 persen.

\section{Pengujian Hipotesis Secara Tunggal (Uji t)}

Uji t dilakukan untuk mengetahui pengaruh variabel bebas secara parsial atau individu terhadap variabel terikat, yang dapat dilakukan dengan melihat nilai $\mathrm{t}$ hitung. Uji $\mathrm{t}$ digunakan untuk mengetahui apakah produk, harga, promosi dan tempat secara parsial nyata berpengaruh atau tidak terhadap kinerja usaha industri kecil roti di Bandar Lampung.
Berdasarkan Tabel 5 dapat diketahui nilai signifikansi dari masing-masing variabel. Terdapat satu variabel yang nyata berpengaruh secara parsial terhadap kinerja usaha industri kecil roti di Bandar Lampung, yaitu harga dengan $(\alpha)=95$ persen dan nilai signifikansi sebesar 5 persen. Sedangkan variabel produk, tempat, dan promosi tidak nyata berpengaruh karena memiliki $(\alpha)=95$ persen dan nilai signifikasi sebesar 26,60 persen sampai 99,60 persen.

Bauran produk tidak nyata berpengaruh terhadap kinerja usaha, yang berarti variabel produk secara parsial tidak nyata berpengaruh terhadap kinerja usaha industri kecil roti di Bandar Lampung, kerena jenis produk yang diproduksi relatif sama. Hasil ini sesuai dengan penelitian Sumantri (2013) tentang kinerja usaha industri pangan di Bogor, yang menyimpulkan bahwa produk tidak nyata berpengaruh terhadap kinerja usaha industri pangan di Bogor.

Bauran harga nyata berpengaruh terhadap kinerja usaha, artinya setiap kenaikan bauran harga yang ditentukan industri kecil akan nyata berpengaruh terhadap kinerja usaha industri kecil roti di Bandar Lampung. Hasil ini sesuai dengan penelitian Triyanto, Sumarjo, dan Prihatanta (2014) tentang analisis bauran pemasaran industri kecil roti, yang menyimpulkan bahwa harga nyata berpengaruh terhadap industri kecil roti di Sleman Yogyakarta.

Bauran tempat yang (dijelaskan dalam empat indikator) tidak nyata berpengaruh terhadap kinerja usaha, karena tempat memiliki kecendrungan yang dapat mempengaruhi minat beli. Dalam penelitian ini tempat tidak berpengaruh terhadap minat beli, karena konsumen tidak terlalu mementingkan tempat industri kecil roti, karena peneliti melihat lokasi industri kecil roti di Bandar Lampung mudah dijangkau sarana transportasi, serta hasil dari persepsi pengusaha cukup penting saja, sehingga tidak akan berpengaruh terhadap kinerja usaha industri kecil roti di Bandar Lampung. Hasil penelitian ini tidak sesuai dengan penelitian Sagala, Affandi, dan Ibnu (2013), tentang kinerja usaha agroindustri kelanting di Desa Karanganyar Kecamatan Gedong Tataan, yang menyatakan bahwa variabel tempat nyata berpengaruh terhadap kinerja usaha agroindustri kelanting di Desa Karanganyar, karena tempat penjualan kelanting dijual di kios-kios pinggir jalan.

Bauran promosi (yang dijalaskan dalam empat indikator) tidak nyata berpengaruh terhadap kinerja usaha, karena industri kecil roti belum melakukan 
kegiatan promosi tetapi hasil dari persepsi pengusaha industri kecil masuk dalam kategori penting. Hasil penelitian ini sesuai dengan penelitian Sesunan, Indriani, dan Listiana (2015) tentang bauran pemasaran terhadap prilaku konsumen pembelian cappucino cincau di Bandar Lampung, yang menyimpulkan bahwa promosi tidak nyata berpengaruh terhadap bauran pemasaran dan keputusan pembelian cappucino cincau di Bandar Lampung.

\section{KESIMPULAN}

Menurut persepsi pengusaha industri keci roti di Bandar Lampung terhadap bauran pemasaran (produk, harga, tempat dan promosi) maka bauran produk, bauran harga, dan bauran promosi termasuk dalam kategori penting, sedangkan bauran tempat termasuk dalam kategori cukup penting. Dilihat dari ROI (Return on Investment), profit margin, dan rasio operasi, maka kinerja usaha industri kecil roti di Bandar Lampung sudah termasuk dalam kategori sangat baik. Unsur bauran pemasaran yang nyata berpengaruh terhadap kinerja usaha industri kecil roti di Bandar Lampung adalah bauran harga, sedangkan bauran lainnya tidak nyata berpengaruh.

\section{DAFTAR PUSTAKA}

Azwar S. 2001. Reliabilitas dan Validitas SPSS. Pustaka Pelajar. Yogyakarta.

Gujarati DN. 2012. Dasar-Dasar Ekonometrika. Terjemahan Mangunson. Salemba Empat. Buku 2. Edisi 5. Jakarta

Kasmir S. 2008. Analisis Laporan Keuangan. Raja Grafindo Persada. Jakarta.
Kurniawan A. 2010. Bauran Pemasaran dan Loyalitas Konsumen. Alfabeta Bandung.

Kotler P. 2000. Teori Marketing Mix. Bumi Aksara. $\quad$ SurabayaMubyarto. 1994. Manajemen Pemasaran Modern. Yogyakarta.

Sagala IC, Affandi MI, dan Ibnu M. 2013. Kinerja usaha agroindusti kelanting di Desa Karanganyar Kecamatan Gedong Tataan Kabupaten Pesawaran. Jurnal Ilmu Agribisnis. 1(1) : 1-92. . http://jurnal.fp.unila.ac.id /index.php/JIA/search/search?simpleQuery = kelanting\&searchField $=$ query. $[8$ Desember 2017].

Sesunan TM, Indriani Y dan Listiana I. 2015. Bauran pemasaran dan perilaku konsumen dalam pengambilan keputusan pembelian cappuccino cincau. Jurnal Ilmu Agribisnis. 3(1) : 1-113. http://jurnal.fp.unila.ac.id/index. $\mathrm{php} / \mathrm{JIA} / \mathrm{search} / \mathrm{search}$ ?simpleQuery=bauran+ pemasaran\&searchField=query $\quad[26 \quad$ Januari 2018]

Sugiyono. 2013. Metode Penelitian Bisnis. CV. Alfabeta. Bandung.

Sumantri. 2013. Kinerja usaha industri pangan di Bogor. Skripsi. Fakultas Ekonomi dan Manajemen. Institut Pertanian Bogor. Bogor.http://repository.ipb.ac.id/jspui/ bitstream/12345678.pdf. [17 Oktober 2017].

Suyanto. 2010. Konsep Dasar Kinerja Usaha. Intermedia.Yogyakarta

Triyanto B, Sumarjo, dan Prihatanta H. 2014. Analisis bauran pemasaran terhadap industri kecil roti di Sleman Yogyakarta. Jurnal Universitas Negri Yokyakarta, 2 (7) : 11-15. http://jurnal.unj.ac.id/index.php/ceress/article/view /7912/3380.[17 Oktober 2017]. 